\title{
THE CONSTRUCTION OF RADICALISM NARRATIONS: A STUDY OF HIJRA HADITH QUOTATION
}

\author{
M. Khoirul Huda \\ El Bukhari Institute (eBI) Ciputat \\ chairool hoeda@yahoo.co.id
}

\begin{abstract}
This article was aimed at exploring the construction of radicalism narrations by using prophetic traditions, which appeared in radical groups namely Islamic State (IS). The data of radicalism narrations were taken from three documents of IS propaganda. This study was a critical discourse analysis (CDA) to reveal the construction of radicalism narrations used by IS. The result of the research showed that IS has quoted some prophetic traditions of hijra and framed it into three main narrations; 1) the narration of establishing caliphate's state, 2) the narrations of classical concept of Muslims' religious territories divided to Dar al-Kufr (Infidel Territory) and Dar al-Islam (Islamic territory), and 3) the narrations of apocalyptic fears. The study concluded that IS had quoted some prophetic traditions to make IS' own narrations to strengthen their ideological mission. Then, these narrations became certain discourse to dominate and alienate others who contradict with IS. Furthermore, this research also included Sara Zeiger's findings about the important of ideological approach to understand and avoid the development of extreme radicalism movements through contrary-narration. In contrast, Ali Ashgar tended to ignore the importance of text/narration/ideological approach to counter the development of extreme radicalism movements.
\end{abstract}

Keywords: Construction, narration, radicalism

\section{Introduction}

One of the most important sacred-texts in the Islamic religion is hadith. Talking about Hadith, there are usually three main aspects to be discussed, such as: text, interpretation and implementation. Every aspect could influence someone's understanding to social relation. As results, text, interpretation, and implementation of hadiths become important problems in Islamic studies. Futhermore, the "implementation" aspect is as the implication of the two other aspects ("text" and "interpretation"), it has currently emerged as interesting phenomena in the discourse of Indonesian moslems scholarship. Because of the implementation of someone's intrepretation from text, it could be harmful to other. It can be seen from the discourse of "the living Quran or hadith" which appears recently. Morever, this idea tries to shift quranic/hadith studies from textual areas to its implementation. At worst, its implementation problem has primarily cristalyzed and become social phenomena (Alfatih, 2007: pp. 114-115).

In inter dicipline study about the relation between religion and politics of violence, there are well known three main theories trying to explain this. Firstly, ideational theory believes that religious language is inspired by extreme religious thought (read: the ideology of violence). It shows that this ideology has become a crucial aspect to bring the emergence of violence sources in the name of religion. Secondly, psycho-social theory emphasizes that ideology is not strong enough to encourage people to engage in violence in the name of religion. The psycho-social experience only has the role of creating extreme interpretations of religious texts. Thirdly, the social movement theory sees that the radical interpretations of religious texts are only as an instrument to support the emergence of social movements which have political objectives. Political violence in 
the name of religion will occur if radical thinking could not tolerate the political and social situation. This is called the theory of political tolerance limits. Moreover, Ali Asghar even considered the more relevant was third theory used to photograph the development of radical groups. (Ali Asghar, 2015). In contrast with Asghar's view in refusing ideology theory, Hayat Alvi as one of the scholars argued that the spread of the Wahhabism ideology was in line with the development of radicalism (Hayat Alvi, 2014). In the context of religious radicalism, radical ideology is constructed through a literal interpretation of sacred texts, such as: the Qur'an and hadith (Budi Hardiman, 2015). The literal interpretation is closely related to extreme behavior. Also, Sarah Zeiger found that extreme violence groups radicalize using some narrations. There are four narrative models, such as: (1) religious or ideological narratives, (2) political narratives, (3) socialheroic narratives, and (4) economic narratives. Religious or ideological narratives use two main concepts, namely: the first, jihad-qital as a personal obligation (fardu 'ayn) and the second, al-wala' wa al-bara which has implications in seeing and dividing the world to become Muslims and non-Muslims (Sara Zeiger, 2016).

The use of hadith in the radicalism narratives has included a religious or ideological narrative. Therefore, in this paper, the author will try to elaborate how the patterns of hadith citation create propaganda narratives used by extreme violence groups, What narratives are used by them in framing the Prophet's hadiths, What narratives are intentionally hidden (exclusion) and what narratives are displayed (inclusion). Overall, the author tried to answer how the citations of hadith in the structures of propaganda narratives were used by extreme violence groups.

\section{Methods}

This research attempted to analyze some propaganda documents owned by extreme violence group, namely Islamic State (IS). The documents were(1) the first edition of Dabiq Magazine,(2) an essay, "Wujub al-Hijrah li Dar al-Nur wa al-Islam wa Tarki Dar al-Kufr wa al-Zalam”, written by Abu 'Abdillah al-Ghazzi al-Muhajir, and (3) Tuba li al-Sham written by Salihal-Munajjid, a prominent salafi scholar from Saudi Arabia. In addition, some other documents were taken from hadith books, Islamic laws books (figh), and mass media informations related to indonesian citizens who migrated to join IS's radical group.

Those documents were analyzed by CDA approach. This approach showed that a discourse activity was as an effort to dominate a certain approved discourse/power and to alienate another disapproved discourse. Therefore, citing hadith and spreading discourse was considered as a domination process. It could involve directly both two processes, namely inclusion and exclusion. The first process was an effort to collect all appropriate texts or narrations related with someone's/groups' politics, ideologies, or dominance to support their interests. The second process was an effort to eliminate another different and incompatible narrations with the structure of someone's/groups' discourses to be developed. By using CDA approach, there were five objectsof analysis (1) acting (discoursing), (2) context, (3) historical aspects (texts), (4) dominance, and (5) ideology. (Ahmad Fauzan, 2014).

\section{Findings and Discussion: Three Hijra Hadiths Frames in Narration Structures used by Radical Groups}

Based on my research, there were three narrations used to frame prophetic hadiths. Firstly, the narration of founding Islamic Government, in this case, the idea to build Islamic caliphate (Dabiq, 1435). Secondly, the narration of infidelity/unfaithstate (Dar al-Kufr read: infidel area) and claim of region governed by moslems as Islamic 
State (Dar al-islam read: Islamic area). By this narration understanding, they campaign all of the moslems in the world to live and join authorized areas which they have been controlled (al-Muhajir, 2016). Thirdly, the narration of "the Sham's country superiority" and "the fear of the end of the world" will come (al-Munajjid, 2015).

Framing Prophet Muhammad's hadiths in the narration of founding caliphate could be found in IS' propaganda media, such as: in the first edition of Dabiq magazine. Dabiq explained the urgency of Hijrah as one way to found the Islamic caliphate revival. In "feature" heading,Dabiq Magazine displayed the article using big font format entitled "From Hijra to Khilafah." This article quoted three hadiths:

\begin{tabular}{|l|l|l|}
\hline No. & \multicolumn{1}{|c|}{ Hadith } & \multicolumn{1}{|c|}{ Reference } \\
\hline 1. & $\begin{array}{l}\text { Al-sam'wa al-ta'ah wa al-hijrah } \\
\text { wa al-jihad }\end{array}$ & $\begin{array}{l}\text { al-Tirmidzi, 1975: v. V, p. 148, number } \\
\text { of hadith 2863 }\end{array}$ \\
\hline 2. & $\begin{array}{l}\text { Khilafah 'ala minhaj al- } \\
\text { Nubuwwah }\end{array}$ & $\begin{array}{l}\text { Ahmad bin Hanbal, 2001: v. XXX, p. } \\
\text { 355 number of hadith 18406 }\end{array}$ \\
\hline 3. & $\begin{array}{l}\text { La tanqati' al-hijrah hatta hatta } \\
\text { tanqati' al-tawbah }\end{array}$ & $\begin{array}{l}\text { Ahmad bin Hanbal, 2001: v. XXVIII, p. } \\
111 \text { number of hadith16906 }\end{array}$ \\
\hline
\end{tabular}

The quoted hadith (narrated by al-Tirmidzi) talking about prophet Muhammad message of emerging ummah for not leaving group (jamaah), hearing and obeying leaders, emigrating and doing concrete jihad (al-Tirmidzi, 1975: vol. 5, p. 148, n. 2863) becomes the introduction and is entailed to the heading of article "from Hijrah to Khilafah". The first paragraph states that caliphate revival is the goal of jihad. This orientation -based on IS opinion- is absent from global project of jihad. IS attempts to answer that crisis by reviving caliphate state as the primary goal of Jihad. "Reviving caliphate is the major purpose which always fulfills the heart of mujahidin since the awakening of consciousness on jihad's duty in this century." some quoted hadiths explain the revival idea of caliphate near to the end of time inspired by the governance in prophet era (Khilafah 'ala Minhaj al-Nubuwwah). This hadith was narrated by Ahmad bin Hanbal in his Musnad (Ahmad bin Hanbal, 2001: vol. XXX, p. 355 number of hadith 8406). The article wants to reach the readers' interest by convincing them to follow their ideologized caliphate which was predicted by prophet Muhammad. It is strongly indicated that IS deliberately did not quote hadith completely because the completion of quoting hadith potentially can dissolve discourse solidity which is being built. In CDA, discoursing is a conscious activity and orient to support such idea. Based on this tenet, discoursing activity always executes exclusion and inclusion by eliminating other narrations that can dissolve its discourse solidity and adopt some narrations to support their idea.

Dabiq placed jihad as a strategy, like Hijrah. The prior process of jihad is leaving homeland (Hijrah) to the IS's authorized state. Hijrah has become mobilization process toward support masses for developing solid military power. Then, it can be concluded that their primary strategy is hijrah-jihad-khalifah (leaving homeland to found caliphate). It is closely related to their statement, "This Jihad is based on Hijrah, sam' wa tha 'ah (hear and obey leader), and i'dad (preparation by training) which head to ribat and combat (qital), and finally honourable death (syahid) or revival of caliphate"(Dabiq. 1st issue, Ramadan $1435 \mathrm{H}$, p. 31-40). That citation unfortunately does not include some hadiths which have canceled the obligation of hijra. Meaning that hijra was over (alBukhari, $1422 \mathrm{H}$ : vol. V, p. 57, number of hadith 3900; al-Bukhari, $1422 \mathrm{H}$ : vol. IV, p. 75 , number of hadith 3077 , vol. V, p. 152, number of hadith 4311 dan al-Nasa'i, $1406 \mathrm{H}$ : vol. VII, p. 145 number of hadith 1469), or different opinion between Moslem scholars or prophet's companion toward Hijrah in its political context (Al-Mawsu'ah al-Fiqhiyyah al-Kuwaytiyyah, pp. XXXXII, 177-183). 
The narration of Hijrah from dar al-kufr (infidel area) to dar al-Islam (Moslem area) is noted in Wujub al-Hijrah li Dar al-Nur wa al-Islam wa Tarki Dar al-Kufr wa alZalam written by Abu 'Abdillah al-Ghazi al-Muhajir.

Al-Muhajir stated that hijra from dar al-kufr to dar al-Islam is an obligation. Based on his statement on verse 97 from Al-Nisa [4], and hadith narrated by Abu Dawud it is believed that the prophet has no responsibility to the moslems who still live in infidel area (Abu Dawud, 2009: vol. IV, p. 413). Moreover, it is claimed that hadith narrated by Sa'id bin Mansur mentions that hijra never ends when jihad still exists (Sa'id bin Mansur, 1982: vol. II, p. 272). Therefore, the author was explaining the concept of dar al-Islam and dar al-kufr which is likely recognized by classical moslem scholarship. Namely, that dar al-Islam is territory where Islamic law is applied ultimately, and dar al-kufr where infidel law is applied. Waves of migration from dar al-kufr to dar al-Islam is an obligation for each Muslim who has the possibility to make it concrete based on Moslem scholars consensus (ijma') (al-Muhajir, n.y: p. 2). Al-Muhajir interpreted that countries within moslem majorities, like Arab Gulf countries, are part of dar al-kufr. He argued that Arab countries today are dar al-kufr, because they apply positive law. In contrast, in IS area, they totally implemented Islamic law. IS claimed that IS'area was based on Quran and Sunna. Therefore, it is obligatory for Muslims to leave these countries and to migrate to IS-controlled areas (al-Muhajir, n.t.: p. 3). According to Al-Muhajir, the concept of dar al-Islam and dar al-kufr was based on some Moslems scholar opinions, such as: Hanafiyyah, Ibn Hazm, Ibn Taymiyyah, and Muhammad bin 'Abd al-Wahhab (alMuhajir, p. 4).

Finally, al-Muhajir develops a discourse that contains threats against those who refuse/defect from the command of emigrating. The defectors are equated with one of prophet's companion, Sa'd bin Khawlah who was once denounced by the Prophet Muhammad for defecting after hijra and jihad (al-Muhajir, n.y.: p. 4).

Quoting some statements from Moslem scholars whose affiliate with multiple schools (mazhab like Hanafi, Hanbali, Zahiri) in their narration, is the process of inclusion over the idea which is affirmed by the author. Clearly, the idea of dar al-Islam conception is established within applying Islamic law in such territory. This narration denied several different opinions among other classic Moslem scholars, because they stated the status of dar al-Islam was based on the ruler/inhabitant of it's own territorial (see: al-Kasani, 1986: vol. VII, p. 130-131; Ibn 'Abidin, 1992: vol. III, p 253; al-Sarakhsi, 1993: vol. X, p. 114; al-Bahuti, tt: vol. III, p. 43; al-Bujayrami, 1995: vol. IV, p. 220). In another word, this act of discoursing is part of excluding other opinions to enhance the author's ideology.

Futhermore, Salih al-Munajjid wrote that there were "The Excellence narrations of Sham" and "The Fear narrations of Coming Doomsday" on his book Tuba li al-Sham. Salih is a salafi's prominent scholar from Saudi Arabia. This book is not written by person who tightly affiliates within salafi-jihadi group. Nevertheless, the content of this book claimed that the excellence narrations of Sham were written in several Islamic texts. As result, it significantly attracted the supporters of extreme jihad to use this book as their argument, both al-Qaeda and IS affiliation. Tuba li al-Sham's book contained hadiths. He framed "the narration of apocalypsing ideology", "the condition of doomdays", and "the signs of doomdays". The framings of those narrations on this book produced a new context and created a set of narrations among extrimist groups in Indonesia to support their arguments. The author of this book also included 14 hadiths to strengthen these groups' ideas. Here are several hadiths used by them: 


\begin{tabular}{|l|l|l|}
\hline No. & \multicolumn{1}{|c|}{ Content of Hadith } & \multicolumn{1}{|c|}{ Referrence } \\
\hline 1. & Angels protect Sham. & $\begin{array}{l}\text { Musnad Ahmad, Sunan } \\
\text { al-Tirmidzi, }\end{array}$ \\
\hline 2. & God guarantees that Sham is secured. & $\begin{array}{l}\text { Musnad Ahmad, Sunan } \\
\text { Abi Dawud, }\end{array}$ \\
\hline 3. & Citizens of Sham is the chosen people. & $\begin{array}{l}\text { Musnad Ahmad, Sunan } \\
\text { al-Tirmidzi, Sahih\} Ibnu } \\
\text { Hibban }\end{array}$ \\
\hline 4. & $\begin{array}{l}\text { Sham is the safe place for protecting faith from } \\
\text { chaos and slander. }\end{array}$ & $\begin{array}{l}\text { Mustadrak al-Hakim, } \\
\text { Hilyat al-Awliya }\end{array}$ \\
\hline 5. & $\begin{array}{l}\text { Sham is the safe place for protecting our Islamic } \\
\text { profile. }\end{array}$ & Mustadrak al-Hakim \\
\hline 6. & $\begin{array}{l}\text { Thaifah Manshurah (Group of Salvation) will } \\
\text { appear in Sham. }\end{array}$ & $\begin{array}{l}\text { Musnad Ahmad, al- } \\
\text { Tirmidzi }\end{array}$ \\
\hline 7. & $\begin{array}{l}\text { Sham is the place where the hypocrites cannot } \\
\text { defeat the believers. }\end{array}$ & Musnad Ahmad \\
\hline 8. & Sham is the home of believers. & Musnad Ah\}mad \\
\hline 9. & Sham is the strongest fortress from the chaos & Musnad Ah\}mad \\
\hline 10. & $\begin{array}{l}\text { All human beings will be gathered in Sham before } \\
\text { the judgment day }\end{array}$ & Musnad al-Bazzar \\
\hline 11. & $\begin{array}{l}\text { Sham is place for the armageddon (malhamah } \\
\text { kubra). }\end{array}$ & Sunan Abi Dawud \\
\hline 12. & Isa will appear for the first time in Sham. & Sahih Muslim \\
\hline 13. & Dajjal will die in Sham & Sahih Muslim \\
\hline 14. & $\begin{array}{l}\text { Ya'juj and Ma'juj will never be able to attack } \\
\text { Sham. }\end{array}$ & Sahih Muslim \\
\hline
\end{tabular}

From above table, it could be concluded that Suriah became important among supporters of the extreme group, especially IS group. It was caused by the narrations using by IS's group. They only took especially hadith and quran related to the apocalypse issues. In those texts, there are many illustrations of horrible things which will happen soon. Then, the secured place for saving peoples guaranteed by God is Sham. Territory of Sham -in this book- is limited only in the current Syria territory.

In conclusion, those three frameworks were taken from those Prophet's hadiths in determined context. Based on CDA's theory, those frameworks have made "the reader" who receives information from the author feels what are told in those texts must be done today. As result, the readers as the supporters and the sympathizers think immediately leaving their hometowns and going to Sham/Syria as a must. In the fact, those frameworks have been success to influence Indonesian's readers who read this book from translated texts. Therefore, the number of Indonesian's arrested citizens who join IS's group is statistically the second biggest after Russians. (See: https://news.detik.com/internasional/d-3561440/, 2017)

\section{Conclusion}

The Narrations of propaganda used by extrimists and violent groups were taken from several hadiths. It could be concluded from above explanations that there were three main frameworks of hadiths used by them; (1) the narrations of strategy for establishing caliphate, (2) the narration of religious territory concept of dar al-kufr and dar al-Islam, and (3) the narration of apocalypse's fears. As result, those frameworks have influenced the people who easily believe in those misinterpretations of hadiths. This study shows the 
reasons why many people have some belief and interest to go to the conflict territory, like Syria. This framing has been success to make common people feel fear and guilty if they do not follow those important narrations from holy texts of Quran and hadiths. Unfortunately, the readers could not diferentiate the intrepetations which have politics and ideologies constructive interests and the texts which have sacred dimensions from holy books to be believed and what is truly revealed from the God and His Messengers. Furthermore, the texts of hadiths which have different contexts and intrepetations among classical Moslem scholars are deliberately eliminated for propagating extreme ideology of violence.

\section{References}

'Abidin al-Hanafi, Ibnu, 1992.Hashiyah Ibnu 'Abidin, (Beirut: Dar al-Fikr), ed. 3.

Al-Baghawi, 1983.Sharal-Sunnah, (Damaskus: al-Maktab al-Islami), ed. 2.

Bahuti al-Hanbali, Mansur bin Yunus al-, Kasyyaf al-Qina', (Beirut: Dar al-Kutub al'Ilmiyyah, tt).

Bujayrami, 1995. Sulayman bin Muhammad al-, Hasyiyah al-Bujayrami, (Beirut: Dar alFikr).

Bukhari, Abu 'Abdillah Muhammad bin Isma'il al-, Sahih al-Bukhari, jilid 5, hal. 178

Hajjaj, Muslim bin, Sahih Muslim, (Beirut: Dar Ihya' al-Turath al-'Arabi).

Hanbal,Abu 'Abdillah Ahmad bin,1995. Musnad Ahmad, (Kairo: Dar al-Hadith), ed. 1.

Hardiman, Budi, 2015. Seni Memahami Hermeneutika dari Schleiermacher sampai Derrida, (Sleman: Penerbit Kanisius), ed. 1.

'Id, Ibnu Daqiq al-, 1987.Ihkam al-Ahkam Sharh 'Umdat al-Ahkam, (Kairo: 'Alam alKutub), ed. 2.

Jawziyyah, Ibnu Qayyim al-, 1394. al-Risalah al-Tabukiyyah, (Jedah: Maktabah alMadani, tt), hal. 24-25, Tariq al-Hijratayn, (Kairo: Dar al-Salafiyyah), ed. 2.

Jurjani, 'Ali bin Muhammad al-, 1983. al-Ta 'rifat, (Beirut: Dar al-Kutub al-'Ilmiyah), ed. 1.

Kasani, 'Ala' al-Din al-, 1986. Bada'i' al-Sana'i', (Beirut: Dar al-Kutub al-'Ilmiyah), ed. 2.

Muhajir, Abu Abdillah al-Ghazi al-,, 2016. Wujub al-Hijrah Li Dar al-Nur wa al-Islam Min Dar al-Kufri wa al-Zulam, (tt: al-Himmah).

Munajjid, Salih al-, Tuba Li al-Sham, (Riyadh: Abeikan, 2015), ed. 2.

Mundziri, Al-, Mukhtasar Sahih Muslim, (Beirut: al-Maktab al-Islami, 1987), ed. 6.

Nawawi, Abu Zakariya Yahya bin Sharaf Al-, Tahrir Alfaz al-Tanbih, (Damaskus: Dar al-Qalam, 1408), ed. 1.

Sara Zeiger, Melemahkan Narasi Teroris di Asia Tenggara, Sebuah Panduan Praktis, (tt: Hedayah, 2016).

Sarakhsi, Muhammad bin Ahmad al-, al-Mabsut, (Beirut: Dar al-Ma'rifah, 1993).

Shafi'i, Muhammad bin Idris Al-, al-Umm, (Beirut: Dar al-Ma'rifah, 1990).

Sijistani,Abu Dawud al-, Sunan Abi Dawud, (Beirut: al-Maktabah al-'Asriyyah).

Suryadilaga, Alfatih,Metodologi Penelitian Living Quran dan Hadis, (Jogjakarta: THPress, 2007), ed.1.

Tirmidzi, Abu 'Isa al-, Sunan al-Tirmidzi, (Halb: Syirkah Mustafa al-Bab, 1975), ed. 2.

Wizarat al-Awqaf wa al-Shu'un al-Islamiyyah al-Kuwayt, Al-Mawsu'ah al-Fiqhiyyah alKuwaytiyyah, (Kuwait: Dar al-Salasil).

\section{Academic Journals}

Ali Asghar, "Islam Politik dan Kekerasan; Tafsir Baru Kekerasan Aktivisme Islam Indonesia", Jurnal Keamanan Nasional, 2015, Vol. I No. 2. 
Umar Fauzan, "Analisis Wacana Kritis Dari Model Faiclough Hingga Mills", Jurnal Pendidik, 2014, Vol. 6 No. 1.

Hayat Alvi, “The Diffusion Of Intra-Islamic Violence And Terrorism: The Impact Of The Proliferation Of Salafi/Wahhabi Ideologies", Middle East Review of International Affairs, 2014, Vol. 18, No. 2.

Pages and Websites

"From Hijrah to Khilafah", Dabiq, Issu 1, Ramadan, 1435.

"Jumlah WNI ISIS Yang Ditangkap Di Turki Terbanyak Kedua di Dunia", Detik.com, 2017, sumber https://news.detik.com/internasional/d-3561440/jumlah-wni-isisyang-ditangkap-di-turki-terbanyak-kedua-di-dunia. Diakses pada 21 Agustus 2017. 